Teosofia: Indonesian Journal of Islamic Mysticism

Volume 6, Number 2, 2017: 153-164 DOI: 10.21580/tos.v6i2.3408

\title{
Religiosity and Prostitution: A Case Study of Argorejo Prostitution in West Semarang
}

\author{
Ary Setiawan \\ Beijing University, Beijing - China \\ ary_stw@gmail.com
}

\begin{abstract}
One of the various illegal jobs in Indonesia is being a prostitute. It is commonly addressed to a woman, who engages in sexual intercourse for money as the source of livelihood. One of the local prostitutions in this country is Argorejo Prostitution at Srikuncorostreet, Argorejo village Kalibanteng, West Semarang, Central Java. What remains unique is that the main activity of prostitutes is not only to serve and to satisfy costumers but also to do some religious activities, such as praying, reciting alQuran, Fasting and others. The questions of this research are: What is the patterns of religiosity of Muslim prostitutes in Argorejo prostitution and Are there Impact of religiosity understanding pattern to their attitudes and deeds of prostitutes. This research produces the data in the form of notes or verbal words from the people or behaviors that can be observed, with the aim to describe the target's condition of the research according to the real source. Using the phenomenology approach with a source of research data in use is the primary data source in the form of information from the field by direct observation at Argorejo Prostitution about activities implemented, then secondary data sources such as books, documentation data Argorejo Prostitution and activity report data Argorejo Prostitution. For data collection techniques that are used, among others: observation method, interview, and documentation. Data analysis using is descriptive analysis to clarify suitable with the problems are studied and that data is compiled and analyzed. The result of this research is descriptive about responses of prostitutes toward Islam religion, including the worship that they do and the perspective of religiosity understanding. Prospect in the next is all prostitutes be able to more aware with their religion although their job who have implemented in the past was a mistake that could be forgiven.
\end{abstract}

Keywords: religiosity; prostitutes; sociology of religion 


\section{A. Introduction}

$\mathrm{P}$ rostitution exists in many forms and has been committed by subjects of different sexes, genders, orientations and ages. Yet, it is not specifically addressed in the law. However, many officials interpreted prostitution as "a crime against decency/morality". Its wide spreads and is tolerated largely, despite its contradiction with popular societal and religious norms. Income fromprostitution may provide money for a more comfortable living than a person might otherwise be able enjoy.

Prostitution blamed for the increasing HIV/AIDS rates in various parts of Indonesia. Prostitutes by themselves may fall victim to psycho-socialproblems, such as multiple personality disorder. When servingtheir customers or dealing with their pimps, they mayabuse physically and mentally. ${ }^{1}$ They are also at-risk of catching HIV/AIDS. A profession as a prostitute is circle of devil because of the effect of it makes some spread of sexually transmitted.

Adultery in Indonesian society is a social disease that is considerably dangerous. Moreover, according Kartini Kartono, free sex (adultery) is no different than prostitution. Actually, it is indeed the same sex with promiscuity or: mixed sexual without rules (prostitution) therefore, adultery included into social problem seriously enough, because it violates decency, destructive the descent, causing dirty disease, disputes and unhappiness in the family, and other calamities.

Many studies struggle to gain demographic information about the prevalence of sex work, as many countries or cities have laws prohibiting prostitution or other sex work. In addition, sex trafficking, or forced sexwork, is also difficult to quantify due to its underground and covert nature. Finding a representative sample of prostitutes given by city can be nearly impossible. Because the size of the population itself unknown. Maintaining privacy and confidentiality in research is also difficult because many prostitutes may face prosecutionand other consequences when their identities revealed. Like in Europe, it is seldom to meet and find virgin girl, and because intercourse without marriage leads to some diseases.

\section{B. Argorejo Prostitution}

Argorejo prostitution, ${ }^{2}$ one of prostitution that located in the Argorejo village, Kalibantengkulon Semarang, thelocalization legalized by the city of Semarang and it becomessexually land sales since1966. Initially Argorejo prostitution is a reallocation

\footnotetext{
${ }^{1}$ Kartini Kartono. Psikologi Abnormal dan Abnormal Seksual (Bamdung: Mandar Maju, 1989).

${ }^{2}$ To avoid it so prostitutes provided a place for them in one place commonly referred to as localization or prostitution. With one state that, the prostitutes can be monitored and briefed or coaching health, religion, etcetera. Interview with Muhammad Taufiq Hidayat 26 years old, he is as manager of Griya Asa PKBI Semarang city. Monday 26 October 2016.
} 
Relogiosity and Prostitution ....

program for prostitutes in the Semarang city. They are widely spread in some areas close to the residential areas. Concerns about the negative impact of prostitution makes Semarang city government builds reallocation for all prostitutes. ${ }^{3}$

Argorejo prostitution with the large 3.5 hectare (ha)is one of prostitution area in the urban Semarang known by public and is a social environment just a village-likein general. In the Municipality of Semarang, there are only two prostitution states i.e., Argorejo in the KalibantengKulon village administration and Gambilangu in the MangkangKulon village administration. Formerly, all prostitutes gathered in village name Karangkembang. The aim is in order to Semarang city be clean, but with a long time that village crowded and fullwith quantity of prostitutes, then the government of Semarang city move them to a hill that so far from citizen. ${ }^{4}$

Relocation project realized in 15 August 1966 in thefirst time dedicated by HadiSubeno (as Regent of Semarang) with circulating letter and this prostitution legalization (No.21/15/17/66), making reallocation prostitutes in Kalibanteng region. Originally this area is hilly land lonely and far from residential areas. Therefore, the name of this area known as Argorejo which means mountain $=$ Argo, affluent $=$ Rejo or the meaning is the mountainous region of prosperity. However, at the beginning of the program relocation, the total of prostitutes that will be moved just a little. For symbolizes the Bitch houses in front of the house fitted with the red-light area in The Netherlands. ${ }^{5}$

The aim of this established this prostitution isto localize Sexually Transmitted Diseases (STDs), and to make easier for monitoring of HIV/AIDS. Another important aim is toreturn to be healthy community and good sociality into society. ${ }^{6}$

Currently, the total of prostitutes is around 735 members that inhabit in the prostitution area. the population of prostitutes who are inhabit there mostly from newcomers. That is from Jepara, Kendal, Pati, Grobogan, Boyolali, Solo, Tegal, Bandung, Brebes and other regions in Central Java, some of others from East Java, West Java and foreign. They assemble suitable with each regions and cooperation because feeling similar fate and have same responsibility. ${ }^{7}$

\footnotetext{
${ }^{3}$ According to data on 2014 source from document in Argorejo office.

${ }^{4}$ Interview with Mr. Shadiqun 64 years old, he is one of administrators in Argorejo prostitution. Saturday, October 10, 2016.

${ }^{5}$ Red light district is an urban area where there is a concentration of prostitution and sex-oriented businesses, such as sex shop, strips clubs, adult theaters, etc. The term originates from the red lights that were used as signs of prostitutions. There are areas in many big cities around the world which have acquired an international reputation as red light districts. Interview withAdib the citizen closed with Argorejo Prostitution. On August, 262016.

${ }^{6}$ According to data on 2016 source from document in Argorejo office

${ }^{7}$ The reasons become prostitutes are diverse, start from economic necessity, destruction of households, until just for fulfill of worldly satisfaction. Please see on Thesis of Muhammad Taufik
} 
Variously development progress especially on building the structure and infrastructure on that place. Withdrawal of money is from of every visitor who comes in every "entrance" of prostitution, this income is from guest come, then officer will ask an assessment Rp.2.000.- for every person. The money used to increase the facility like construct internal roads, and the others used for social funds allocated to help victims of natural disasters. ${ }^{8}$

Argorejo prostitution complex area there is a grave from one of disseminator of Islam religion, he is Soen An Ing (Sunan Kuning) the grave places are being on sub district of Kalibanteng Kulon, the position is in top of small hill, beside north of Muriadi Raya Street. Because of this grave usually mention the Argorejo prostitution with SK, SunanKuning. Actually, SK mention is for some people thatmean Sri Kuncoro, because the Argorejo prostitution being on Sri Kuncoro street. Unfortunately, until now, mostly people always wrong to mention SK (Sunan Kuning). Although it place being on localization area but the pilgrim continually come to pilgrimage. ${ }^{9}$

Every time, datas about total of prostitute could change becouse controlling and some factors about a problem they want to be a prostitute, moreover Argorejo now is the biggest prostitution at Central Java and also the biggest in Indonesia when Doli prostitution closed, then requestincrease, but the official do not accept all newcomer because they would not take a big risk, especially for their healthy about Sexually Transmitted Diseases (STDs) moreover HIV/AIDS, if in urgent condition they will make selection first because of carefully from official in order to this localization always get predicate the cleanest. ${ }^{10}$

In Argorejo prostitution has include systematic area because the management makes maximum effort by administrator and some people who have been to acts and keep suitable as care with prostitutes. There are four element communities point in Argorejo

Hidayat, (0103513156) Study of Basic Education Science Concentration Program, Graduate Program, Semarang State University 2015. "Presespsi Pelajar Sekolah Menengah Pertama Sekitar Resosalisasi Argorejo terhadap Perilaku Seksual sebagai Sumber Belajar Pendidikan Kesehatan Reproduksi dan Seksual", 45.

${ }^{8}$ Formerly, Argorejo prostitution was managed by the government of Semarang city, currently is managed by the community of society Argorejo village, (the transition of management was conducted in 1991). On 1985 chance the regent of Semarang city wants to region Dawung hamlet Pudak Payung, but it is ignored because that moving has impact on pollution of river which the water is used the citizen for daily activity, like washing, take bath and drinking. Finally, that prostitution lives permanently in Argorejo village Kalibanteng Kulon until nowadays. Interview with Irwanto on of administrator official at Argorejo prostitution. On August 262015.

${ }^{9}$ Interview with Masaid the citizen of Argorejo village. On August 26, 2015.

${ }^{10}$ Interview with Mr. Sumardi is a chief of RT 5 RW 4 and an administrator in their region. On August 27, 2016. 
Relogiosity and Prostitution ....

prostitution, that communities consisting of administrator, pimp, prostitute and boyfriend ofprostitute. ${ }^{11}$

It needs an extra careful attitude, because discussing religion is a social problem, but in the reality for understanding is so have individual character, the understanding and concerning as religion by someone so depends on background and personality. It makes a difference pressure in every person, and makes religion become as deep from their personality and privacy ofsomeone. Religion has been successful to built civilization of world, because it gives about mean of life and feeling piece.

There are some definitions of religion which indicate any different understanding according to individual. ${ }^{12}$

\section{The Meaning of Religion for Prostitutes Life}

Religion brings mission as carrier peacefulness and balancing of life, not only to every human but also among peer's creature of God in this world. In the missions of alQuran have rāhmahlil 'al-alamin (mercy and peacefulness for entire). But in history of reality, religion mission is not alwaysarticulate. Religion is a reference for becoming a hint when something happens a situation or condition that being outside of scope and ability of human because his character is supra-natural so be hoped could solves the problems that non empiric. ${ }^{13}$

Religion from an anthropological approach is seenas a cultural phenomenon and thereby the function and the role of religion in social structure become obvious as of principles and modes of knowing the frame for understanding of society toward their environment and guidance society. ${ }^{14}$

\footnotetext{
${ }^{11}$ Description of element communities' point, first administrator, it is a group of officials that be chosen democratically for leads the proceed of prostitution business and order to make effort rehabilitation of prostitutes. The chief of Argorejo prostitution nowadays is Suwandi Eko Putranto he is also the chief of PMN (Paguyuban Mucikari Nasional). Second is pimp, usually they called as "mami" or "papi" is a man who has business in Argorejo place (lodge), except for operate the prostitution business the job of pimp are responsibility of the safety, health, and rehabilitation of their prostitutses. Third is prostitute, according the rule of Argorejo prostitution the age of them minimum is 18 years old and maximum belong 3 years to work on Argorejo prostitution, the last is boy friend of prostitutes or usually they called with "Kiwir" or "Tukimin" or "Tukijo" is man who make relation with prostitute and became a operator of karaoke, the task of them are accompany the prostitute, deliver and pick up the prostitute, also make satisfy desire of prostitute. Muhammad Taufik Hidayat, "Presespsi Pelajar Sekolah Menengah Pertama..." 46-7.

${ }^{12}$ Komaruddin Hidayat, Psikologi Beragama Menjadikan Hidup Lebih Nyama dan Santun (Jakarta Selatan: Hikmah PT Mizan Publik, 2006), 16.

${ }^{13}$ Dadang Kahmad, Sosiologi Agama (Bandung: Remaja Rosdakarya, 2009), 130.

${ }^{14}$ Yusuf Rahman, Islam and Society in Contemporary Indonesia (Jakarta: PPS-IIS UIN Syarif Hidayatullah, 2006), 215.
} 
Concerning that mean with function of religion is a role to solve a troubles and problems that being in society could not solved with empiric because there is a limited ability and uncertainty. Therefore, be hoped religion implement that function so for human feel prosperous, safe, stable and others. Thomas F. O'dea write six function of religion, that is: a) As supported and a comforter, b) Facility of transcendental relation by adoration and worship ceremony, c) Strengthener of norms and values, d) Giving identity, e) Maturity of religion.

The existence of religion is as guidance livelihood man for better and straight suitable with norms of humanity. Religion also teaches about regulation of live, although for individual or social. But in the reality not all person who has religion understand and implement the ideology, instruction and doctrine of their religion. There are have some factors to cause the person or mankind does not implement their live suitable with religion who already he had. For example, are difficulty economic factor, it makes stimulus to do whatever job for fulfill their living cost. Secondly is education factor, it is very influential in the comprehension religiousness someone, and then is social factor (environment) where human live is like reality being.

World's whore is also not free from the above factors. Although they are largely believing religion as belief of life direction and to know the commands and prohibitions of religion that must be implemented. But with a variety of conditions and choke them with being forcedor consciously abandon the ideology of their religion.

World's whore was hooked in the black world. However, it does not mean God is not present permanently in that black world. Because for God. He isnot only present in the mosque, association of recitals and places that are considered holy. Prostitution is loaded leaves room in which in that place God still wants to present.

There are people who consider the necessity of implementation arrangements sex. Therefore, sex drive makes major effect on humans like a blazing flame. The fire could be useful for humans, but it could also blast if flared too big. Similarly, with sex, can build human personality, but also can destroy humanness.

There are some reasons of the important of religion for prostitute life, because religion is source of moral, guidance of truth, information about God, and because religion gives guidance of spirituality for prostitutes in their highs and lows of life.

According interview with some of prostitutes at Argorejo prostitution from 23 respondents answer $95.65 \%$ of them said religion as guidance of their life, and 4,34 \% answer religion just for formality. In this case the prostitutes admit religion as guidance and as instruction oftheir life, and one of them giving opinion about the function of religion L said, religion is so important for her life, because it is a guidance of her life, human without religion will be break, and religion make her knows also gives her instruction to remember God, so if she commits sins sometimes she feels disappointed, 
Relogiosity and Prostitution ....

regret because of economic factor she gets this job and there is feel in a deep hearth to out in this place and try to repentant. ${ }^{15}$

Further information, see on draft VI. To respond that statement the prostitute makes a religion as guidance for their life in order to they can be saved by religion although they have been commit many big sins, religion provides social cohesion to help maintain social solidarity through shared rituals and beliefs, as social control to enforce religious based in morals also norms to help maintain conformity, control society, and it offers meaning and purpose to answer any existential questions. Religion in individual life gives functions as system that includes the certain norms to guidance human life.

If prostitute who has been repentant seriously so, forgiveness that will be gotten, because the repentant as mercy sign by Allah, while sin and mercy could not be in one soul. So, if Allah approves the repentant, He will hide His forgiveness because the faith is a beginning and verifying in finally. ${ }^{16}$

Islam is a religion which gives importance to both inner belief as well as outer work. Being a Muslim does not entail that one merely carries out acts of ritual worship, nor that one only holds certain belief in the heart without if being apparent in one's actions. Psychological theories hold the religion is an affair of the individual and springs from sources within the individual, whereas sociological theories hold that religion is an affair of the group of society and that individual religiosity stems from social sources. Intellectualist psychological theories interpret the religion as stemming essentially from human reason while emotionalist theories trace the roots of religion to the emotional side human nature. ${ }^{17}$

\section{Religion, Sex and Feminism in The History}

Many religious feminists from a variety of traditions see religion as a major cultural force shaping people's lives, which must be addressed. For example, late 19th century US suffrage leaders such as Matilda Joslyn Gage and Elizabeth Cady Stanton argued that without changes in religion, deep social changes would not be sufficient to bring about justice. ${ }^{18}$

\footnotetext{
${ }^{15}$ Interview with PM prostitution from Brebes. 25 years old August 26, 2015.

${ }^{16}$ Margareth Smith, Rabi'ah Pergaulatan Spiritual Perempuan, translation, by Dra. Jamilah Baraja (Surabaya: Risalah Gusti,1997), 66.

${ }^{17}$ Macolm Hamilton, The Sociology of Religion Theoretical and Comparative Perspectives, Second edition (London: Routledge, 2001). 25.

${ }^{18}$ Gage M. J., Woman, Church and State. Stanton EC and the Revising Committee (eds) (New York: Arno Press, 1972), The Woman's Bible Coalition Task Force on Women and Religion (Seattle, 1974).
}

Teosofia: Indonesian Journal of Islamic Mysticism, Volume 6, Number 2, 2017 
Such discourse is needed to be increasingly obvious as women fight for reproductive choices in the global arena. In the US, the on-going struggle to attain and maintain abortion rights is impeded by the Catholic bishops. In the recent elections they focused virtually all of their attention on candidates' positions on reproductive health. Likewise, in Poland where abortion laws have only recently and with great struggle been liberalized, and in Ireland where much remains to be done, the impact of repressive theology has public policy implications. Religiously-based ethics too often result in public policy that constrains choices and usurps women's moral agency. ${ }^{19}$

It is hard for most people to think of women and Christianity in the same breath with anything but negative associations, and some feminists, Mary Daly first and now others, have written off Christianity as useless unto harmful for developing sexual ethics. Others might take an apologetic approach, such as saying that early Christian teachings are simply products of their day and therefore excusable. But in the face of such Vatican teachings as Veritatis Splendor, the most recent encyclical which rehearsed the same old sexual ethical issues in woman-trivialising and sex-negative ways, such explanations are insufficient to the damage which is done to women in the name of the Divine. ${ }^{20}$

Contemporary feminist work in Christian ethics is full of resources for the next century despite the sometimes morally embarrassing Christian past. Happily, feminist groups such as the Religious Consultation on Population, Reproductive Health and Ethics from an interreligious perspective, and Catholics for a Free Choice from a Catholic Christian perspective, among others, offer spirited alternatives. Our hope is to contribute to the foundational work necessary to enhance those efforts.

They undertooksuch work at a time when HIV/AIDS and other sexually transmitted diseases are on the rise, especially for women. We are motivated by the need to safeguard ourselves and our children from sexual violence. And we are urged-on by the scandalous lack of resources for most of the world's women when it comes to sex education, contraceptives and abortion possibilities. These dimensions of contemporary life both frame the problems we address and help us to prioritize our theological agenda. Otherwise, charges that religions are part of the problem rather than part of the solution ring true. ${ }^{21}$

To that end, we are engaged in careful exploration of the roots of many contemporary understandings of sexuality, noting the broad influence of the world's religions, especially Buddhism, Christianity, Hinduism, Islam and Judaism. It cannot be over emphasized howcomplex and different each of these traditions is from one another. Still,

\footnotetext{
${ }^{19}$ Gage.

${ }^{20}$ Gage.

${ }^{21}$ Gage.
} 
Relogiosity and Prostitution ....

although we live on a religiously diverse planet, there are some common concerns which help to set a universal agenda from the start.

It is then obvious that sexuality and sexual behavior have been of great concernfor the early Church, from whose teachings both the Orthodoxand the Roman Catholic Churches draw their inspiration. Most of the pronouncements of the early Church relate to abortion, adultery and fornication, and most of them condemn stronglyand punish harshly those sexual practices. The personalpositions of different early Church apologists and churchfathers were later officially embraced as canons at variousregional and ecumenical councils, then codified as canon law byEmperor Justinian I in the 6th century, and then used bynational Orthodox Churches as spiritual and disciplinary guidesin the everyday life of their congregations for centuries. Untilvery recently the Orthodox Churches did not see the need todraft documents on social and moral issues comparable to thepapal encyclicals, either because of their close collaborationwith precommunist state authorities or because of theirpersecution by the communist regimes. Therefore, someobscure canons that are still used by influential father confessors in the Eastern European countries are discussed here.

Some American readings of early Church writings onsexuality, especially abortion, provide a conservative interpretation suggesting that the overwhelming majority of thosewriters condemned abortion performed at any time ofgestation, even when it saved the mother's life (for such a viewpoint, seeAn Orthodox View of Abortion, 1988; Bole,2000). However, the pro-life commentators seem to ignorethe historical context in which those writings were produced, and to read more than even the writers wanted to convey.

Sexual practices in the Roman Empire were quite liberal bytoday's standards (Brown, 1989). Prostitution, adultery, pederasty, homosexuality, and even incest were part of theeveryday life and not necessarily punishable by law. In Romanlaw, abortion and infanticide were indistinguishable, since aninfant could be destroyed at any time before being recognizedby thepaterfamiliasas a legal person. Jewish law allowedabortion during the first forty days of pregnancy. Severalcenturies before, Aristotle (384-322 BCE) had distinguishedbetween vegetable, animal and human life, and had arguedthat the human soul entered the body only when the fetuswas fully formed, that is, at forty days for males and eightydays for females. The implication was that abortion beforethat time did not kill a living being (body and soul), and thuswas not morally condemnable. Christians distanced themselves from such views and practices, but not all of them did itright from the very beginning, and not all adopted the mostextreme view of sexuality, as some contemporary commentators would have us believe.

One of the earliest Christian writings to address the issueof abortion was the briefDidache, also known as the Teachingof the Twelve Apostles, which most scholars date to the latefirst century or early second century. It read that "you shallnot murder a child by abortion nor kill that which is born" (Didache2, 1-2), but the statement did not 
specify when thefetus could be considered a child in his mother's womb. TheEpistle of Barnabas, a Greek writing preserved complete inthe fourth-century Codex Sinaiticus (see Bibliorum Codex Sinaiticus Petropolitanus, 1969) but written sometime before, echoed the Didache without bringing a measure of precision:"Thou shalt not murder a child by abortion, nor again shaltthou kill it when it is born"(Epistle of Barnabas19:5).

A more definitive pronouncement was formulated byTertullian of Carthage (160$225 \mathrm{CE}$ ). Defending the Christiansagainst false accusations of secret crimes, he wrote that in our case, murder being once for all forbidden, we maynot destroy even the fetus in the womb.... To hinder abirth is merely a speedier man-killing; nor does it matterwhether you take away a life that is born, or destroy onethat is coming to the birth. That is a man which is going tobe one; you have the fruit already in the seed. ${ }^{22}$

\section{The Impact of Religiosity Understanding for Prostitutes to Their Attitudes and Deeds}

Religion leads man towards a consciousness of moral responsibility in everything he or she does, whether great or small, there is a constant stress on establishment to right and the abolition of wrong in every religion. Thus, religion is required for the construction of a worldly frame for the possible spiritual development of human, the moral knowledge of man forces moral responsibility on man. The morality should live and die with the human existence in this world.

All of religion significantly influence individual attitude and it is interpreting of human, and the most important about condition of individual existence. ${ }^{23}$ Religion is no matter for formality and just ritual or symbols also a belief about strength of spiritual, religion is included the aspect cognitive for religious deed. Religion is an autonomous tradition that cannot utilized for fulfilling economic needs. ${ }^{24}$

The original function of religion is guidance of attitude and moral, so for understanding of religion influence that attitude of people because of faith and belief in personality construction. As to the effectiveness its influence depends on the individual and personality.

\footnotetext{
${ }^{22}$ Lavinia Stan, "Eastern Orthodox Views on Sexuality and the Body", Women's Studies International Forum 33 (2010), 38-46.

${ }^{23}$ Ethos is one of chapter from philosophy which has mean as knowledge to investigate which are the good and bad with notice the deed of human as far could be known by idea of human. The function of ethos to reflect how the human must life in order to will s uccess as human that's realable to has responsibility became a lead in this world (khalifah fi al-arḍi). Please see on Suparman Syukur, Etika Religius, (Yogyakarta: Pustaka Pelajar, 2004), 1.

${ }^{24}$ Bryan S. Turner, Agama dan Teori Sosial, translation by I. Ridwan Muzir (Yogyakarta: IRCISOD, 2006), 69.
} 
Relogiosity and Prostitution ....

Every religion has rule and obligation that must be obeyed from their follower, and the rules of that will influence the attitude from the follower, but if implement the obligation of God just for formality and not suitable that religion wants so the understanding of religion is a little. Religion has big influence on pattern of life a follower.The function of worship is to purify the soul and educate in order to aim the right way, if it is not achieved or can achieve that aim, so it is not worship and not be accepted by Allah, moreover makegenerates censure on the doer, for example in the prayer, which is personal worship of concrete.

\section{Conclusion}

To sum up, the religiosity of the prostitutes in West Semarang Argorejo implies that in reality any human being no matter how despicable they are, they still have awareness of the existence of God. They cannot completely deny the existence of God apart from their actions that violate religions. People may claim that they are unreligious and pervert at all. However, based on this research, most of them still think that religion is important as they say that religion is the source of morality, the guidance of truth, and something related to God. This once again emphasizes that humans in their consciousness are always built-in God's spot where it will radiate by itself without being activated.

\section{Bibliography}

Hamilton, Macolm. The Sociology of Religion Theoretical and Comparative Perspectives, Second edition. London: Routledge, 2001.

Syukur, Suparman. Etika Religius. (Religious Ethics). Yogyakarta: PustakaPelajar, 2004.

Turner, Bryan S. Religion and Social Theory (Agama dan Teori Sosial), trans. by I. RidwanMuzir. Yogyakarta: IRCISOD, 2006.

Smith, Margareth. Rabi'a The Mystic and Her Fellow-Saints in Islam. (Rabi'ah: Pergaulatan Spiritual Perempuan) trans. by Dra. Jamilah Baraja. Surabaya: Risalah Gusti,1997.

Hidayat, Komaruddin. Psikologi Beragama Menjadikan Hidup Lebih Nyaman dan Santun. Jakarta Selatan: Hikmah PT Mizan Publik, 2006.

Kahmad, Dadang. Sosiologi Agama. Bandung: RemajaRosdakarya, 2009.

Kartono, Kartini. Psikologi Abnormal dan Abnormal Seksual. Bamdung: Mandar Maju, 1989.

Rahman, Yusuf. Islam and Society in Contemporary Indonesia. Jakarta: PPS-IIS UIN Syarif Hidayatullah, 2006. 
Stan, Lavinia. "Eastern Orthodox Views on Sexuality and the Body" Women's Studies International Forum 33 (2010), 38-6.

Gage MJ, 1883/1972. Woman, Church and State. Arno Press, New York. Stanton EC and the Revising Committee (eds), 189511974. The Woman's Bible Coalition Task Force on Women and Religion, Seattle. 